\title{
Validation of the EuroQol quality of life questionnaire on stroke victims
}

\author{
Élen B. Pinto ${ }^{1,2}$, lara Maso ${ }^{1,2}$, Renata Nóbrega Ribeiro Vilela², \\ Luciana Corrêa Santos², Jamary Oliveira-Filho ${ }^{1}$
}

\begin{abstract}
Objective: To validate a quality of life scale, EuroQoL, on stroke patients. Method: 67 patients were scored simultaneously for EuroQoL-5 Dimensions (EQ-5D), NIH Stroke Scale (NIHSS) and modified Barthel Index (mBI). Pearson test was used to correlate each scale. Additionally, 31 patients were examined by two independent evaluators on the same day through application of EQ-5D. Kappa statistics were used to evaluate interobserver agreement. Results: EQ-5D showed good correlation with both stroke severity (NIHSS, $r=-0.404, P<0.001)$ and degree of impairment on activities of daily living ( $\mathrm{mBI}, r=0.512$, $P<0.001)$. We noticed a good interobserver agreement $(k>0.60)$ in all dimensions evaluated $(P<0.01)$. Conclusion: We demonstrated that $E Q-5 D$ is reproducible and valid on evaluation of quality of life in patients post stroke in Brazil.
\end{abstract}

Key words: quality of life, EuroQoL, stroke.

\section{Validação do questionário de qualidade de vida EuroQol em vítimas de acidente vascular cerebral}

\section{RESUMO}

Objetivo: Validar uma escala de qualidade de vida, o EuroQoL-5D, em pacientes com acidente vascular cerebral (AVC). Método: O EuroQoL-5 Dimensões (EQ-5D), NIH Stroke Scale (NIHSS) e o Índice de Barthel modificado (IBm) foram aplicados simultaneamente a 67 pacientes. $O$ teste de Pearson foi utilizado para correlacionar as escalas. Adicionalmente, 31 pacientes foram avaliados por dois investigadores independentes, no mesmo dia para aplicação do EQ-5D. O índice Kappa foi utilizado para avaliar a variabilidade interexaminadores. Resultados: $O$ EQ-5D mostrou boa correlação com a gravidade do déficit neurológico (NIHSS: $r=-0,404 ; P<0,001$ ) e com o grau de restrição às atividade da vida diária (IBm: $r=0,512 ; P<0,001$ ). Houve uma boa concordância interexaminadores $(k>0,60)$ em todas as dimensões avaliadas $(P<0,01)$. Conclusão: $O$ EQ-5D é reprodutível e válido na avaliação da qualidade de vida de pacientes pós-AVC no Brasil. Palavras-chave: qualidade de vida, EuroQoL, acidente vascular cerebral.

\section{Correspondence} Jamary Oliveira-Filho Rua Waldemar Falcão 2106 / apt. 201 40296-710 Salvador BA - Brasil E-mail: jamaryof@ufba.br

Received 19 June 2010 Received in final form 1 November 2010 Accepted 9 November 2010
World-wide, including developing countries, chronic degenerative disease prevalence is increasing, causing a change on universal morbimortality profile $^{1}$. These diseases may cause limiting physical disabilities or permanent impairment on survivors. The advances in treatment have increased life expectancy, but also the possibility to remain with residual functional incapacity, with significant impact on quality of life (QoL) ${ }^{2}$.
According to this, the construct of quality of life has been an important part of reflection of multidimensional concept of health ${ }^{3-5}$. A large diversity of QoL evaluation instruments have been developed for research and clinical practice, both as self-applied questionnaires and interviews. The development and validation of instruments to evaluate QoL has become an important area of research. However, to demonstrate their validity, these instru- 
ments require evaluation in different research centers and by various researchers on several populations ${ }^{6}$.

The EuroQol-5 dimensions (EQ-5D) is already translated to several languages, is frequently used as measure of QoL and has showed internal consistency when applied to general population and in groups of patients with various diseases ${ }^{7}$.

Despite being translated to Portuguese language, the EQ-5D is not yet validated in Brazil.

This paper aims to demonstrate the reproducibility and validity of this instrument and its utility on strokerelated research and clinical practice ${ }^{8}$.

\section{METHOD}

All patients were recruited from the Stroke Clinic of the Federal University of Bahia, with a clinical diagnosis of stroke, regardless of the number of events. Stroke was defined as a new neurological focal deficit with duration longer than 24 hours ${ }^{9}$. Exclusion criteria included people with communication and comprehension difficulties and those who refused to participate. All participants signed a consent term, agreeing to participate voluntarily and the study was approved by a ethics committee of Federal University of Bahia.

Between July and November 2005, we sequentially applied the following scales: EQ-5D, modified Barthel Index $(\mathrm{mBI})$ and the National Institutes of Health Stroke Scale (NIHSS). The EQ-5D is a generic instrument which approaches five dimensions of health (mobility, self-help, habitual activities, pain, anxiety/depression), each one with three levels of abnormality. A composite QoL score was calculated based on previously published criteria, where scores varied between 0 and 1 , with death receiving a score of 0 and 1 being the best state of health ${ }^{10}$. A score of 0.86 is considered the reference score for the general population and 0.78 for individuals between 65 and 74 years old ${ }^{11}$.

To evaluate the functional profile of the patients, we applied the $\mathrm{mBI}$, which categorized them in groups of independence. A total $\mathrm{mBI}$ score of 50 suggest complete independence, 46-49 slight dependence, 31-45 moderate dependence, 11-30 severe dependence and 10 complete dependence ${ }^{12}$.

The severity of stroke was measured by the NIHSS, which offers a quantitative evaluation of neurological disability, giving us the severity of the stroke measurement through the assessment of conscience level, language, neglect, visual field, extra ocular movements, muscular strength, ataxia, dysarthria and sensory loss. The higher the score, more severe the stroke ${ }^{13}$.

To verify the interobserver agreement, between January and March 2008, we applied the EQ-5D in a separate group of patients from the same Stroke Clinic, who were evaluated independently by two investigators on the same day.

The Statistical Package for the Social Sciences (SPSS) version 13.0 was utilized for statistical analysis. To correlate scores between scales we applied the Pearson test; and we used the kappa index to compare the interobserver agreement. We considered a verypoor association values <0.20; poor, 0.20-0.39; moderate, 0.40-0.59, good, $0.60-0.79$ and excellent $>0.80$. The significance level was established as $5 \%$.

\section{RESULTS}

The convenience sample selected for the correlation tests was composed of 67 individuals with mean age of $59.3( \pm 13.3)$ years, $56.2 \%$ female. The neurological deficit measured by the NIHSS showed a median of 4 and the mean $\mathrm{mBI}$ was of $43.6( \pm 7.1)$. EQ-5D showed a good correlation with both NIHSS $(r=-0.404, \mathrm{P}<0.001)$ and $\mathrm{mBI}(\mathrm{r}=0.512, \mathrm{P}<0.001)$ (Table 1$)$.

Thirty patients with mean age of 54 years range 23 to 74 years, with $58 \%$ female were evaluated for interobserver agreement. We noticed a good interobserver agreement $(k>0.60)$ in all dimensions evaluated $(\mathrm{P}<0.01)$ (Table 2).

\section{DISCUSSION}

To study QoL in health is essential, because this parameter interferes on definition of treatment, on evaluation of its results and could act as starting-point for primary attention and rehabilitation. The EQ-5D is a generic instrument that tries to reach all important aspects related to health and it reflects the disease impact on the individual. A prospective study carried out in the United

Table 1. Correlation between quality of life (EQ-5D) and widely used scales in stroke research: National Institutes of Health Stroke Scale (NIHSS) and modified Barthel Index (mBI).

\begin{tabular}{ccc}
\hline $\begin{array}{c}\text { Scale correlated } \\
\text { with EQ-5D }\end{array}$ & $\begin{array}{c}\text { Pearson } \\
\text { correlation }(r)\end{array}$ & P-value \\
\hline $\mathrm{NIHSS}$ & -0.404 & $<0.001$ \\
$\mathrm{mBI}$ & 0.512 & $<0.001$ \\
\hline
\end{tabular}

Table 2. Interobserver agreement on dimensions of EQ-5D.

\begin{tabular}{lc}
\hline Dimensions of EQ-5D & Interobserver agreement (kappa) \\
\hline Mobility & $\mathrm{K}=0.621^{*}$ \\
Usual activities & $\mathrm{K}=0.654^{* *}$ \\
Pain & $\mathrm{K}=0.747^{* *}$ \\
Self-care & $\mathrm{K}=0.652^{* *}$ \\
Anxiety/depression & $\mathrm{K}=0.754^{* *}$ \\
\hline
\end{tabular}

${ }^{*} \mathrm{p}<0.01 ;{ }^{* *} \mathrm{p}<0.001$. 
Kingdom validated the EQ-5D on stroke survivors, considering it short, simple and allowing the majority of patients to answer it without assistance ${ }^{14}$.

Most literature reviewed of the EQ-5D compares it with other generic and specific measurements utilized in quality of life evaluation ${ }^{15}$. The present study demonstrated that a significant correlation exists between QoL and level of functionality in victims of stroke. However, this is not enough to be considered as substitute data, as represented by the moderate correlation between $\mathrm{mBI}$ and the EQ-5D. Even though the QoL related to health and functional status are concepts extremely related, they represent different components of individual condition of health ${ }^{16}$. The survivors of stroke have a widespread variety of symptoms that surpass the individual's peformance of motor activities, and, for not capturing the psicosocial related aspects of health, the mBI would not be enough to evaluate the stroke impact to the individual's life $\mathrm{e}^{1,2,15}$. According to this, a recent study which evaluated functionality using $\mathrm{mBI}$ and QoL with the EQ$5 \mathrm{D}$, found a portion of patients functionally independent with a poor QoL, and a proportion of dependent patients with a good QoL ${ }^{17}$. Similar data was found in another research, which documented that independent patients could have a compromised QoL ${ }^{18}$.

A study that compared the $\mathrm{mBI}$ with the EQ-5D found a significant and stable relationship between these scales, demonstrating that EQ-5D is a valid instrument with discriminative capacity among the different levels of disease incapacity. As the $\mathrm{mBI}$ is more widely utilized, the author suggests its application as an alternative evaluation measurement in patients unable to assert their QoL. However, the same author recognizes a roof effect of $\mathrm{mBI}$, which is not representative beyond a period of six months ${ }^{19}$.

The severity of stroke measured with NIHSS demonstrated a predominance of individuals considered to have a mild stroke severity. This probably reflects our patient sample, composed of patients able to arrive at an outpatient clinic. As expected, a significant correlation was found between stroke severity and QoL, but again many patients with mild deficits showed poor QoL scores.

The assessment instruments must be reproducible through time, they have to reproduce equal or much similar results, in two or more administrations to the same patient, considering, naturally, that the clinical stage has not been modified. A good inter-observer agreement rate of the instrument was demonstrated in this study, with a good achievement in all its dimensions.

The EQ-5D has been used in several studies as preferred measurement to evaluate QoL in stroke survivors ${ }^{15,20-24}$. Other studies have validated its utilization in different chronic disease and in general population, sug- gesting its application on clinical research and in epidemiological studies of QoL in health ${ }^{25-30}$. As in other studies, it was not possible to examine the aspects to convergent validation, because there is not a QoL goldstandard measurement ${ }^{8}$.

In conclusion, it was possible to demonstrate the reproducibility and validity of EQ-5D in a population of stroke patients, as an instrument with measurement properties demonstrated by several groups, which makes it useful to be utilized on evaluation of QoL in research and on clinical practice.

\section{REFERENCES}

1. Suenkeler I, Nowak M, Misselwitz B, et al. Timecourse of health-related quality of life as determined 3, 6 and 12 months after stroke: relatioship to neurological deficit, disability and depression. J Neurol 2002;249:1160-1167.

2. Lai S, Perera S, Duncan PW, Bode R. Physical and social functionin after stroke: comparison of the Stroke Impact Scale and Short Form-36. Stroke 2003;34:488-493.

3. Minayo MCS, Hartz ZMA, Buss PM. Qualidade de vida e saúde: um debate necessário. Ciência \& Saúde Coletiva - Revista da Abrasco 2000;5:17-18.

4. Seidl EMF, Zannon CMLC. Qualidade de vida e saúde: aspectos conceituais e metodológicos. Ciência \& Saúde Coletiva - Revista da Abrasco 2004;20: 590-599.

5. World Health Organization Group. The Word Health Organization Quality of Life Assessment (WHOQOL) position paper from the Word Health Organization. Soc Sci Med 1995;41:403-409.

6. Ciconelli RM, Ferraz MB, Santos W, Meinão I, Quaresma MR. Tradução para língua portuguesa e validação do questionário genérico de avaliação de qualidade de vida SF-36 (Brasil SF-36). Rev Bras Reumatol 1999;39:143-150.

7. Wolfs CAG, Dirksen CD, Kessels A, Willems DCM, Verhey FRJ, Severens JL. Performance of the EQ-5D and the EQ-5D+C in elderly patient with cognitive impairtments. Health Quality Life Outcomes 2007;5:1-10.

8. EuqoQol Group. EQ-5D: a standardised instrument for use a measure of health outcome EQ-5D translations. Available at www.euroqol.org. Accessed may 18, 2010.

9. National Institute of Neurological Disorders and Stroke. Special report from the National Institute of Neurological Disorders and Stroke: classification of cerebrovascular diseases, III. Stroke 1990;21:637-676.

10. Kopec JA, Willison KD. A comparative review of four preference-weighted measures of health-related quality of life. J Clin Epidemiol 2003;56:317-325.

11. Kind P, Hardman G, Macran S. UK populations norms for EQ-5D. University of York Centre for Health Economics, Discussion paper 172, 1999.

12. Shah S, Vanclay F, Cooper B. Improving the sensitivity of the Barthel index for stroke rehabilitation. J Clin Epidemiol 1989;42:703-709.

13. Cincura C, Pontes-Neto O, Neville IS, et al. Validation of the National Institutes of Health Stroke Scale, Modified Rankin Scale and Barthel Index in Brazil: the role of cultural adaptation and structured interviewing. Cerebrovascular Dis 2009;27:119-122.

14. Dorman PJ, Waddell F, Slattery J, Dennis M, Sandercook P. Is the EuroQol a valid measure of health-related quality of life after stroke? Stroke 1997;28:1876-1882.

15. Haacke C, Althaus A, Spottke A, Siebert U, Back T, Dodel R. Long-term outcome after stroke: evaluating health-related quality of life using utility measurements. Stroke 2006;37:193-198.

16. Scattolin FAA, Diogo MJD, Colombo RCR. Correlação entre instrumentos de qualidade de vida relacionada à saúde e independência funcional em idosos com insuficiência cardíaca. Caderno de Saúde Pública 2007;23: 2705-2715.

17. Fischer $U$, Anca D, Arnold M, et al. Quality of life in stroke survivors after local intra-arterial thrombolysis. Cerebrovascular Dis 2008;25:438-444.

18. Kong KH, Woon VC, Yang SY. Prevalence of chronic pain and its impact on health-related quality of life in stroke survivors. Arch Phys Med Rehabil 2004;85:35-40.

19. van Exel VNJA, Scholte op Reimer WJM, Koopmanschap MA. Assessment of post-stroke quality of life in cost-effectiveness studies: the usefulness of Barthel Index and the EuroQol-5D. Quality Life Res 2004;13:427-433. 
20. Xie J, Wu EQ, Zheng Z, et al. Impact of stroke on health-related quality of life in the noninstitutionalized population in the United States. Stroke 2006;37:2567-2572.

21. Pickard AS, Johnson JA, Feeny DH. Responsiveness of generic health-related quality of life measures in stroke. Quality Life Res 2005;14:207-219.

22. Pickard AS, Johnson JA, Feeny DH, Shuaib A, Carriere KC, Nasser AM. Agreement betwen patient and proxy assessment of health-related quality of life after stroke using the EQ-5D and health utilities index. Stroke 2004;35:607-612.

23. Myers JA, McPherson KM, Taylor WJ, Weatherall M, McNaughton HK. Duration of condition is unrelated to health-state valuation on the EuroQol. Clin Rehabilitation 2003;17:209-215.

24. Ahmed S, Mayo NE, Wood-Dauphinee S, Hanley JA, Cohen SR. Response shift influenced estimates of change in health-related quality of life poststroke. J Clin Epidemiol 2004;57:561-570.

25. Harrison MJ, Davies LM, Bansback NJ, Ingram M, Anis AH, Symmons DP. The validity and responsiveness of generis utility measures in rheumatoid arthritis: a review. J Rheumatol 2008;35:592-602.

26. Matza LS, Boye KS, Yurgin N. Validation of two generic patient-reported outcome measures in patients with type 2 diabetes. Health Quality Life Outcomes 2007;31:47

27. Wee HL, Lke WC, Li SC, et al. Cross-cultural adaptation and validation of Singapore Malay and Tamil versions of the EQ-5D. Ann Acad Med Singapore 2007;36:403-408.

28. Hughes DA. Feasibility, validity and reliability of the Welsh version of the EQ-5D health status questionnaire. Quality Life Res 2007;16:1419-1423.

29. Chang TJ, Tarn YH, Hsieh CL, Liou WS, Shaw JW, Chiou XG. Taiwanese version of the EQ-5D: validation in a representative sample of the Taiwanese population. J Formos Med Assoc 2007;106:1023-1031.

30. Schweikert $B$, Hahmann H, Leidl R. Validation of the EuroQol questionnaire in cardiac rehabilitation. Heart 2005;92:62-67. 